\title{
Belowground ectomycorrhizal communities in three Norway spruce stands with different degrees of decline in the Czech Republic
}

\author{
Journal Article \\ Author(s): \\ Peter, Martina; Ayer, Francois; Cudlin, Pavel; Egli, Simon \\ Publication date: \\ 2008 \\ Permanent link: \\ https://doi.org/10.3929/ethz-b-000103280
}

Rights / license:

In Copyright - Non-Commercial Use Permitted

Originally published in:

Mycorrhiza 18(3), https://doi.org/10.1007/s00572-008-0166-5 


\title{
Belowground ectomycorrhizal communities in three Norway spruce stands with different degrees of decline in the Czech Republic
}

\author{
Martina Peter • François Ayer • \\ Pavel Cudlín • Simon Egli
}

Received: 29 September 2006 / Accepted: 18 January 2008/Published online: 8 February 2008

(C) Springer-Verlag 2008

\begin{abstract}
We investigated the ectomycorrhizal communities on the roots of adult trees and seedlings associated with three Norway spruce stands in the Czech Republic using morphological and molecular tools. The stands had different degrees of forest decline due to air pollution. The aims of the study were to obtain information about the belowground ectomycorrhizal community in a heavily damaged spruce forest and to assess whether missing ectomycorrhizal fungal partners could be one of the reasons for the observed lack of regeneration. The ectomycorrhizal species richness on the roots of adult trees was significantly lower in the heavily damaged site Mumlavska hora than in the other two, but less drastically so than that found in a fruitbody survey. The roots of adult trees and seedlings were fully mycorrhizal at this site although they were less species-rich. The most abundant ectomycorrhizal species on the root system of adult trees in all three forest stands was Tylospora fibrillosa, a member of the athelioid clade. It made up over $60 \%$ of root tips in Mumlavska hora and its proportion was at least twice that in the other two sites. This species was also an efficient colonizer of roots from seedlings, in particular, in the most damaged site. The different soil properties in this site may have caused the ob-
\end{abstract}

M. Peter $(\bowtie) \cdot$ F. Ayer $\cdot$ S. Egli

Swiss Federal Research Institute WSL,

Zuercherstrasse 111,

CH-8903 Birmensdorf, Switzerland

e-mail: martina.peter@wsl.ch

P. Cudlín

Institute of Landscape Ecology,

Academy of Sciences of the Czech Republic,

37005 Ceske Budejovice, The Czech Republic served differences in the ectomycorrhizal species richness and composition. For example, cation exchange capacity and soil base saturation were lower and the soil more often saturated. However, the number of living trees and their defoliation status may well directly impact the ectomycorrhizal species composition by presumably affecting the amount of carbon delivered to the symbiotic fungal partners. Athelioids and thelephoroids are an important component of the belowground ectomycorrhizal community in most temperate and boreal forests, but the role they play might even be more crucial in stressed forest ecosystems. Based on our results, we suggest that factors other than missing ectomycorrhizal inoculum constrain natural regeneration in the heavily damaged site Mumlavska hora.

Keywords Ectomycorrhizal community · Forest decline . ITS-PCR-RFLP · Inoculum potential · Forest regeneration

\section{Introduction}

From the end of the 1970s, extensive damage to forests occurred in many industrial regions, with acute or chronic injuries on broadleaves and conifers. In Europe, the first reports of forest decline concerned the border mountains in eastern Bavaria, the Black Forest, the Weser Mountains, the Rhine region, and eastern Europe. It was thought to be mainly caused by air pollution (Innes 1993), resulting in a variety of symptoms, especially needle-loss, needleyellowing, and reduced stand growth (Schulze et al. 1989). A chain of stress-response events that results in progressive deterioration in tree health and mortality in at least part of the population distinguishes decline from other forest diseases (Manion 1991; Percy 2002). Several studies examine Norway spruce forests in heavily polluted regions in 
the Krkonose Mountains, also known as the Giant Mountains. In this area, among Bohemia, southern Poland, and Germany, the forest decline was mainly attributed to soil acidification due to high concentrations of air pollutants. The main pollutant was $\mathrm{SO}_{2}$ from coal-fired power stations which used a high-sulfur brown coal from local open-pit mines in Tertiary deposits (Henzlik et al. 1997; Hruška and Cudlín 2003). In this region, increased defoliation was thought to be caused by the synergistic effects of chronic natural and immission stress impacts, which led to premature senescence. Herbivores did not seem to be involved (Polák et al. 2007). Pure spruce forests declined extensively and then largely failed to regenerate. Although the air quality has improved in the Krkonose Mountains and the stand states have generally stabilized or improved since the 1990s (Vacek and Matějka 1999), many forest sites are still heavily damaged and only a few percent of trees have survived; most show extensive defoliation and no regeneration.

Pollutants deposited on soils not only act directly on the assimilative organs and roots of trees, but they also led to soil acidification, altered nutrient availability, increased solubility of toxic cations, and modified floristic composition and microbial community (Schulze et al. 1989). Some studies report that ectomycorrhizal communities have changed, possibly as a correlation with forest decline (Jansen 1991; Fellner and Pešková 1995; KielszewskaRokicka et al. 1997). A decline in the fruitbody production of ectomycorrhizal species has been reported to precede any visible damage to the forest (Fellner and Pešková 1995). The reduction in ectomycorrhizal species richness associated with forest decline observed in fruitbody surveys seems to manifest itself also at the root-level according to morphotype analyses (Kielszewska-Rokicka et al. 1997). Ectomycorrhizal fungi play a crucial role in forest tree health and regeneration by enhancing nutrient acquisition, drought tolerance, and pathogen resistance of their hosts (Smith and Read 1997). It is therefore important to document the presence and composition of ectomycorrhizal communities in severely damaged forests and examine whether absence or composition can explain the observed lack of forest regeneration.

In this context, we participated in a cooperative EU case study that was designed to investigate the constraints on natural regeneration of Norway spruce in a declining forest stand in the Krkonose Mountains (Cudlín et al. 2003). Our specific project focused on the ectomycorrhizal ecology of the stand. Our primary objectives were to determine the belowground ectomycorrhizal community in a heavily damaged spruce forest and to compare it with the ones in two spruce forests situated in the Krkonose Mountains showing a different degree of decline. We hypothesize that the three sites show different ectomycorrhizal species compositions and that a lack of ectomycorrhizal fungal partners could be affecting the observed lack of regeneration.

\section{Materials and methods}

Study sites and sampling schemes

Within the framework of the original 1999 cooperative EU study, three $50 \times 50 \mathrm{~m}$ research plots, Mumlavska hora, Alzbetinka, and Modry dul were selected in pure spruce (Picea abies L. Karst.) forests in the Krkonose Mountains (CZ). These plots are three of the six permanent research plots established by the Institute of Landscape Ecology, CAS (CZ) in 1992. They cover a horizontal pollution gradient from west to east (regarding the anemo-orographic systems according to Jeník 1961) and a vertical gradient (meters above sea level). They have been used to characterize a mean response of adult Norway spruce trees to climatic and immission stress impacts along these gradients (Schwarz 2001). The Mumlavska hora plot was exposed to strong air pollution in the 70 s along the western border of the Krkonose Mountains, the so-called breaker zone. Alzbetinka is situated $7 \mathrm{~km}$ southeast from Mumlavska hora and was less exposed to air pollution than plots at the breaker zone. It is situated on the winward part of the anemo-orographic system (Jeník 1961) and was thus more exposed to air pollution than the sites on the leeward part in the middle of the Krkonose Mountains and sites in the northeastern part of the Krkonose Mountains where Modry dul is situated (Fig. 1). The three forest sites showed different degrees of decline as indicated by defoliation and loss of secondary shoot formation. Defoliation provides information

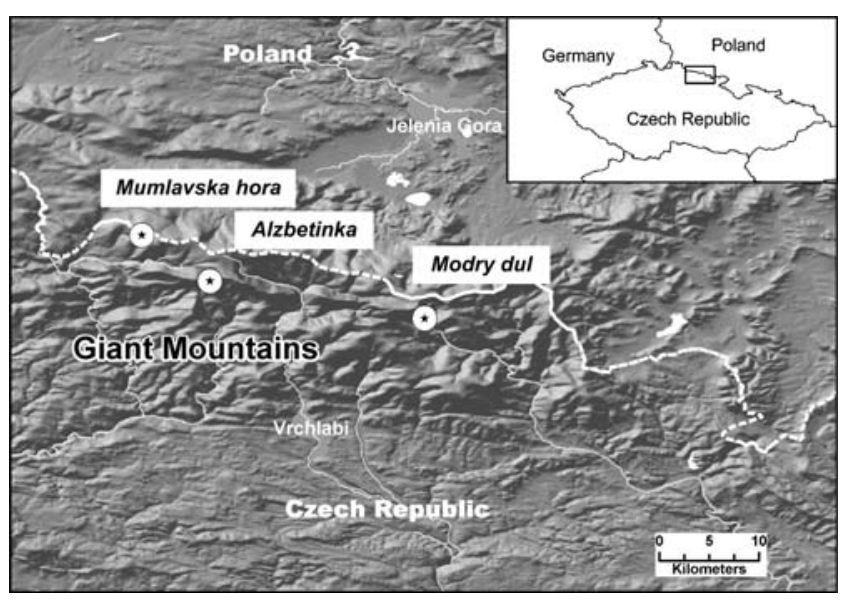

Fig. 1 Location of the three study sites in the Giant/Krkonose Mountains 
about the extent of crown damage, and the percentage of secondary shoots indicates the extent of crown structure transformation, i.e. the rate needed to replace prematurely abscessed needles (cf. Cudlín et al. 2001; Cudlín et al. 2003; Polák et al. 2007). Secondary shoots are defined according to the ICP Forests Programme (http://www. icp-forests.org) as shoots that have developed from dormant buds on the stem or branches. In Norway spruce, secondary shoots develop along the main branches to replace older shoots that have lost their needles. These shoots can therefore serve as substitutes for insufficient crown parts, play a role in crown regeneration, and in developing an optimal form for the given environmental conditions (Gruber 1994). At the stand level additional indicators of decline are the canopy cover, the percentage of dead trees, and the abundance of natural regeneration (Table 1). According to our assessment of the indicators at these sites, we refer to the degree of decline of the three forest stands as ranging from more to less damaged (Mumlavska hora $>$ Alzbetinka $>$ Modry dul).

The Mumlavska hora plot is located in a forest with only $3 \%$ living spruce trees, a mean defoliation of $52 \%$, and a high percentage of secondary shoots $(88 \%)$. Natural regeneration was nearly absent. The Alzbetinka plot is situated in a forest where $46 \%$ of living trees had a mean defoliation of $45 \%$ and $69 \%$ of secondary shoots and regeneration was poor. The Modry dul plot had a relatively preserved forest cover with $62 \%$ of living trees showing a mean defoliation of $42 \%$ and $62 \%$ of secondary shoots. Natural regeneration was abundant. (Cudlín et al. 2001) and Bonifacio et al. (2006) describe additional site characteristics.

In autumn 2000 (September 23 to 29), we surveyed and collected the fruitbodies of macromycetes inside the three permanent plots and in areas extending $200 \mathrm{~m}$ outside the plots and compiled a species list.

To assess the belowground ectomycorrhizal species composition, we randomly sampled roots from five selected adult trees per plot (distributed over the whole plot). We collected 20 random root samples within a distance of 1 to $4 \mathrm{~m}$ around each tree, yielding a total of 100 samples per plot, as follows: A short piece $(\sim 3 \mathrm{~cm})$ of lateral root containing ectomycorrhizas was extracted with tweezers from the organic horizon (approximately upper $5 \mathrm{~cm}$ ) and

Table 1 Description of the three permanent study sites situated in the Krkonose Mountains (CZ)

\begin{tabular}{|c|c|c|c|}
\hline & Mumlavska hora & Alzbetinka & Modry Dul \\
\hline Altitude (meters a.s.1.) & 1,185 & 1,192 & 1,237 \\
\hline Annual mean temperature $\left({ }^{\circ} \mathrm{C}\right)$ & 2.5 & 3.1 & 3.8 \\
\hline Average precipitation $\left(\mathrm{mm}\right.$ year $\left.^{-1}\right)$ & 1,500 & 1,450 & 1,390 \\
\hline Vegetation unit & Sphagno-Piceetum molinietosum & $\begin{array}{l}\text { Athyrio alpestris- } \\
\text { Piceetum typicum }\end{array}$ & $\begin{array}{l}\text { Calamagrostio villosae- } \\
\text { Piceetum fagetosum }\end{array}$ \\
\hline Prevailing soil types (FAO classification) & Humic, histo-humic podzol & Humic podzol & Entic podzol \\
\hline Soil $\mathrm{pH}\left(\mathrm{H}_{2} \mathrm{O}\right)$ of $\mathrm{O}_{\mathrm{h}}$ horizons & 3.8 & 3.6 & 3.8 \\
\hline Soil CEC of $\mathrm{O}_{\mathrm{h}}$ horizons ${ }^{\mathrm{a}}\left(\mathrm{mmol} \mathrm{kg}^{-1}\right)$ & 241 & 265 & 290 \\
\hline Soil base saturation of $\mathrm{O}_{\mathrm{h}}$ horizons $(\%)$ & 12.7 & 20.9 & 49.7 \\
\hline Soil $\mathrm{C} / \mathrm{N}$ ratio of $\mathrm{O}_{\mathrm{h}}$ horizons & 20.7 & 27.8 & 27.8 \\
\hline $\begin{array}{l}\text { Mean annual concentration of } \mathrm{SO}_{2} \text { in } 1991 \\
\text { according to model data of } \mathrm{Hadaš}(1994)\left(\mu \mathrm{g} \mathrm{m}^{-3}\right)\end{array}$ & 30 & 26 & 20 \\
\hline Mean age of trees ${ }^{\mathrm{b}}$ (years) & 185 & 205 & 135 \\
\hline Diameter at breast height ${ }^{\mathrm{c}}(\mathrm{cm})$ & 36.6 & 36.6 & 43.5 \\
\hline Mean tree height ${ }^{\mathrm{d}}(\mathrm{m})$ & $\begin{array}{l}\text { Not possible to measure, } \\
\text { many breaks }\end{array}$ & 19 & 23.4 \\
\hline Mean tree defoliation ${ }^{\mathrm{e}}(\% \pm \mathrm{SE})$ & $52 \pm 2.1$ & $45 \pm 1.7$ & $42 \pm 0.9$ \\
\hline Mean secondary shoots ${ }^{\mathrm{e}}(\%+\mathrm{SE})$ & $88 \pm 4.2$ & $69 \pm 4.1$ & $68 \pm 2.2$ \\
\hline Living trees ${ }^{\mathrm{e}}(\%)$ & 3 & 46 & 62 \\
\hline Canopy cover $(\%)$ & 2 & 29 & 54 \\
\hline Natural regeneration & Absent & Poor & Abundant \\
\hline
\end{tabular}

The parameters were assessed in the year 1999 (Novak 2001).

${ }^{a}$ Cation exchange capacity, determined by a modified Gillman's method (Gillman 1979) in $0.1 \mathrm{M} \mathrm{BaCl}_{2}$

${ }^{\mathrm{b}}$ Official mean values according to the Czech forestry administration

${ }^{\mathrm{c}}$ Measured by calliper

${ }^{\mathrm{d}}$ Measured by laser clinometer

${ }^{\mathrm{e}}$ Estimated according to the manual of the ICP Forest programme using binoculars (http://www.icp-forests.org). $S E$ standard error of 10, 39, and 96 trees situated in $50 \times 50 \mathrm{~m}$ plot for Mumlavska hora (with few surrounding trees), Alzbetinka and Modry dul, respectively. Calculated from the total of living and dead (standing and lying) trees in the plot 
put into $1.5 \mathrm{ml}$ tubes. To obtain information about the ectomycorrhizal species composition in deeper soil layers, we took at least three additional samples from each tree using a soil corer (diameter $4.5 \mathrm{~cm}$ ) to a depth of $30 \mathrm{~cm}$. The samples were split into three equal segments and fine roots were extracted, put into $1.5 \mathrm{ml}$ tubes, and marked separately as "top" $(0-5 \mathrm{~cm})$, "middle" $(5-20 \mathrm{~cm})$, and "bottom" $(20-30 \mathrm{~cm})$. The root samples were stored at $4{ }^{\circ} \mathrm{C}$ for no longer than 1 month until used for the molecular analysis of ectomycorrhizas. In the laboratory, we randomly selected one mycorrhizal root tip per sample for DNA analysis.

From each plot we excavated at least two and up to six spruce seedlings if available. We then described the ectomycorrhizal species composition on their roots in terms of their morphological characteristics combined with a molecular analysis of a representative sample (1-5) from each morphotype.

Bioassay with soil monoliths

We excavated two soil monoliths (diameter $15 \mathrm{~cm}$, depth $15 \mathrm{~cm}$ ) ranging 1-3 $\mathrm{m}$ from each of the five trees per plot and from an additional five dead trees in the Mumlavska hora plot. The five dead trees were situated at least $25 \mathrm{~m}$ from the nearest living tree. Monoliths were transferred into pots and seeded with Norway spruce. The seeds came from below the Modry dul plot and were collected from 15 trees. They were washed in sterile water with charcoal and in $3 \% \mathrm{H}_{2} \mathrm{O}_{2}$ and 30 of them were seeded per monolith. After a culturing period of four months in the greenhouse we sampled the roots and pooled them per plot and per living and dead trees in Mumlavska hora. The percentage of germination fluctuated between $63 \%$ and $72 \%$ and the percentage of surviving seedlings between $62 \%$ and $69 \%$. We carefully washed the roots and viewed all of them under a dissecting microscope. The aim was to detect as many of the species present as possible. Therefore, we classified the mycorrhizas into morphotypes according to color, texture, and shape of the mantle, as well as the presence and appearance of extramatrical hyphae and rhizomorphs (Agerer 1991). From each morphotype, a representative number of root tips were sampled per site and living or dead tree for molecular identification (154 root tips in total).

Molecular analysis of ectomycorrhizas

Ectomycorrhizal fungi on single root tips were identified by comparing RFLP patterns obtained from digestions of the ITS region of rDNA, which had been amplified from extracted DNA by PCR as described in Peter et al. (2001a, b). In short, DNA was isolated from single mycorrhizal root tips following the CTAB extraction protocol described by Kårén et al. (1997). The primers ITS1 and ITS4 were used to amplify the ITS region. Dyelabeled deoxicytidine triphosphates ([F] dCTPs, Applied Biosystems) were added to the PCR mixture to detect fragment length after digestion on an ABI Prism 310 Genetic Analyser using GeneScan and Genotyper software (Applied Biosystems). RFLP-patterns were produced by three separate digestions using the enzymes MboI, HinfI, and TaqI (MBI Fermentas). We compared the RFLP patterns to a reference database of approximately 230 different patterns obtained from the fruitbodies of ectomycorrhizal species associated with Norway spruce using the software Taxotron (Pasteur Institute, Paris, France). The database comprised 60 local vouchers of 45 different ectomycorrhizal species. In total, we analyzed 374 ectomycorrhizal root tips from adult trees (upper layer 313; middle layer 39; bottom layer 22), 36 root tips from seedlings excavated in the sites, and 154 root tips from bioassay seedlings.

\section{Statistics}

We applied ANOVA in SYSTAT (SYSTAT 2000) to test for differences in species richness, Shannon's index of diversity $\left(H=-\Sigma p_{i} * \ln p_{i}\right)$, and differences in the abundances of single RFLP types among plots. In the full model, we introduced the percentage of total defoliation of the replicate trees as a covariate. Since $p$ values of the covariate were high $(p=0.98$ and 0.82 for dependent variables RFLP types and Shannon's index, respectively) we removed it from the final model. Statistical analyses were performed with RFLP type data from adult trees. We used the five trees per site as replicates. To test the influence of plot differences on the number of RFLP types, we used rarefaction (Hurlbert 1971) because the number of successfully analyzed root tips differed from replicate tree to replicate tree. The estimated number of RFLP types was calculated from a sample size of 10 mycorrhizas, which was the lowest number of RFLP patterns within a replicate. Model assumption of normality held for the analyses as visually checked by plotting residuals on a quantile-quantile plot and verified by a one-sample Kolmogorov-Smirnov test. To test whether the total defoliation of the five replicate trees differed among plots, we applied the nonparametric Kruskal-Wallis analysis of variance since the residuals differed from the normal distribution.

The similarities of the ectomycorrhizal species composition among the replicate trees were analyzed with principal coordinate analysis (PCOA) using Van der Maarels index in MULVA-5 (Wildi and Orlóci 1996). RFLP type abundances were square root transformed to reduce the influence of abundant types. 
Table 2 Ectomycorrhizal macromycetous species of which fruitbodies were observed in the three sites

Mumlavska Alzbetinka Modry dul hora

\begin{tabular}{|c|c|c|c|}
\hline \multicolumn{3}{|l|}{ Amanita fulva } & 2 \\
\hline \multicolumn{3}{|l|}{ Amanita rubescens } & 2 \\
\hline \multicolumn{3}{|l|}{ Amanita submembranacea } & 1 \\
\hline Clavulina cinerea & & 13 & \\
\hline Clavulina cristata & & 81 & 129 \\
\hline Clavulina rugosa & & 6 & \\
\hline Cortinarius acutus & & & 4 \\
\hline Cortinarius albovariegatus & & 12 & \\
\hline Cortinarius anomalus & & 10 & 3 \\
\hline Cortinarius anthracinus & & & 11 \\
\hline Cortinarius brunneus & & 5 & 8 \\
\hline Cortinarius casimiri & & & 4 \\
\hline Cortinarius croceoconus & & 3 & 9 \\
\hline Cortinarius croceus & 4 & 3 & 2 \\
\hline Cortinarius decipiens & & 6 & 2 \\
\hline Cortinarius eburneus & & 1 & \\
\hline Cortinarius evernius & & 11 & \\
\hline Cortinarius flexipes & & 13 & 18 \\
\hline Cortinarius obtusus & & & 5 \\
\hline Cortinarius rigens & & 3 & 5 \\
\hline Cortinarius sanguineus & & 2 & \\
\hline Cortinarius sp & & 12 & 17 \\
\hline Cortinarius sp (Dermocybe) & & 2 & \\
\hline Cortinarius sp (Telamonia) & & 8 & \\
\hline Cortinarius sp (parvannulatus) & & 13 & \\
\hline Cortinarius spilomeus & & 3 & \\
\hline Cortinarius valgus & & 12 & \\
\hline Hygrophorus olivaceoalbus & 1 & 8 & 10 \\
\hline Hygrophorus pustulatus & 9 & 3 & 2 \\
\hline Inocybe assimilata & & & 19 \\
\hline Inocybe boltonii & & & 9 \\
\hline $\begin{array}{l}\text { Inocybe flocculosa } \\
\text { var. flocculosa }\end{array}$ & & & 4 \\
\hline Inocybe soluta & & 5 & 10 \\
\hline Laccaria bicolor & & & 2 \\
\hline Laccaria laccata & & & 14 \\
\hline Lactarius badiosanguineus & & 3 & 3 \\
\hline Lactarius lignyotus & & & 4 \\
\hline Lactarius mittissimus & & & 3 \\
\hline Lactarius rufus & & 6 & 19 \\
\hline Lactarius sphagneti & 4 & 1 & \\
\hline Porphyrellus porphyrosporus & & & 1 \\
\hline Russula emetica & 5 & 11 & 18 \\
\hline Russula laricina & & & 3 \\
\hline Russula ochroleuca & & & 6 \\
\hline Xerocomus badius & & & 4 \\
\hline $\begin{array}{l}\text { Total No. of mycorrhizal } \\
\text { fruitbodies }\end{array}$ & 23 & 256 & 353 \\
\hline $\begin{array}{l}\text { Total No. of mycorrhizal } \\
\text { species }\end{array}$ & 5 & 27 & 33 \\
\hline
\end{tabular}

The number of fruitbodies per species and the total number of fruitbodies or species per site are given.

\section{Results}

Fruitbody occurrence of macromycetes

From 23 to 29 September 2000, we observed the fruitbodies of 45 different macromycetous species that form ectomycorrhizas (Table 2). We found fruitbodies of only five ectomycorrhizal species in the most damaged site Mumlavska hora compared to 27 in Alzbetinka and 33 in Modry dul. These five species (Cortinarius croceus, Hygrophorus pustulatus, Hygrophorus olivaceoalbus, Lactarius sphagneti, Russula emetica) formed 23 fruitbodies, whereas a total of 256 fruitbodies were counted in Alzbetinka and 353 in Modry dul.

Ectomycorrhizal species composition on the roots of adult spruce trees

We identified a total of 40 different RFLP types from the 236 (Mumlavska hora: 71, Alzbetinka: 70, and Modry dul: 95) successfully analyzed root tips sampled in the upper 5-cm horizon (Table 3). Twenty-four of them matched references in the database. Tylospora fibrillosa was the most abundant in all three sites and was significantly more abundant in the most damaged site Mumlavska hora, where it made up $62 \%$ of the mycorrhized root tips. In the Alzbetinka, it made up $31 \%$ and in Modry dul 25\% (Table 3). There were significant differences in abundance between sites with $R$. emetica, which was abundant in Alzbetinka (20\%), and with Tylospora asterophora, which was abundant in Modry dul (10.5\%) (statistical data not shown). Both species' richness and diversity were significantly lower in Mumlavska hora, with an average of 3.8 species per 10 root tips compared to 5.2 species in Alzbetinka and 6.6 species in Modry dul (Table 4).

When plotting the total defoliation of the five replicate trees per plot against their observed number of mycorrhizal RFLP types or against the Shannon's index of diversity, a negative correlation between these parameters was indicated (Fig. 2). However, since the total defoliation of the trees differed significantly in the three plots (Kruskal-Wallis statistic $=10.096 ; p=0.006$ ), we cannot separate the plot from the defoliation effect. Within the sites, no defoliation effect was detectable (the covariate was not significant: $p=$ 0.98 , dependent variable RFLP types; $p=0.82$, dependent variable Shannon's index; see "Material and methods").

When looking at the similarities of the RFLP type compositions of the five trees within each site, the most damaged site Mumlavska hora was separated on the first PCOA-axis from the other two in ordination analysis (Fig. 3). The ectomycorrhizal species compositions within the less damaged site Modry dul were more dissimilar than the ones within the other two based on this analysis, with replicate 
Table 3 Ectomycorrhizal community on the root system of adult spruce trees in the three study sites Mumlavska hora, Alzbetinka, and Modry dul

\begin{tabular}{|c|c|c|c|c|c|c|c|c|c|c|}
\hline & \multicolumn{2}{|c|}{ Mumlavska hora } & \multicolumn{2}{|c|}{ Alzbetinka } & \multicolumn{2}{|c|}{ Modry dul } & \multicolumn{4}{|c|}{ Deeper soil layers } \\
\hline & & & & & & & \multicolumn{2}{|c|}{ B $(5-20 \mathrm{~cm})$} & \multicolumn{2}{|c|}{$\mathrm{C}(20-30 \mathrm{~cm})$} \\
\hline & & & & & & & $\mathrm{Alz}$ & Mod & Alz & Mod \\
\hline Tylospora fibrillosa & 62.0 & (5) & 31.4 & (5) & 25.3 & (5) & 1 & 3 & 1 & 1 \\
\hline Russula emetica & 1.4 & (1) & 20.0 & (4) & 2.1 & (1) & 1 & 1 & - & - \\
\hline Clavulina group ${ }^{\mathrm{a}}$ & - & & 8.6 & (2) & 12.6 & (3) & 5 & 3 & 6 & 1 \\
\hline Russula ochroleuca & 2.8 & (1) & 7.1 & (2) & 9.5 & (5) & 1 & 3 & - & 1 \\
\hline Tylospora asterophora & 2.8 & (2) & 1.4 & (1) & 10.5 & (5) & - & 1 & - & 1 \\
\hline Phialocephala fortinii ${ }^{b}$ & 7.0 & (3) & 1.4 & (1) & 2.1 & (2) & - & - & - & - \\
\hline Lactarius rufus & - & & 7.1 & (3) & 1.1 & (1) & - & - & - & - \\
\hline RFLP12 & 1.4 & (1) & 1.4 & (1) & 4.2 & (2) & - & - & - & - \\
\hline Cortinarius group $1^{\mathrm{a}}$ & - & & 2.9 & (1) & 3.2 & (2) & - & - & - & - \\
\hline RFLP06 & 5.6 & (2) & - & & - & & - & - & - & - \\
\hline Hygrophorus olivaceoalbus & 2.8 & (1) & 1.4 & (1) & 1.1 & (1) & - & - & - & - \\
\hline Cortinarius caninus & - & & 4.3 & (2) & - & & 1 & - & - & - \\
\hline Russula xerampelina & - & & - & & 4.2 & (2) & - & 1 & - & - \\
\hline RFLP11 & 2.8 & (1) & 1.4 & (1) & - & & - & - & - & - \\
\hline RFLP14 & 2.8 & (1) & 1.4 & (1) & - & & - & - & - & - \\
\hline Thelephora terrestris & 1.4 & (1) & 1.4 & (1) & 1.1 & (1) & - & - & - & - \\
\hline RFLP01 & - & & 1.4 & (1) & 2.1 & (2) & 1 & - & - & - \\
\hline Xerocomus badius & - & & - & & 3.2 & (2) & - & - & - & - \\
\hline RFLP15 & 2.8 & (1) & - & & - & & - & - & - & - \\
\hline Cortinarius group $4^{\mathrm{a}}$ & - & & 1.4 & (1) & 1.1 & (1) & - & - & - & - \\
\hline RFLP03 & - & & 1.4 & (1) & 1.1 & (1) & - & - & - & - \\
\hline Hygrophorus pustulatus & 1.4 & (1) & - & & 1.1 & (1) & - & - & - & 1 \\
\hline Mycelia sterilia type $44 / 57^{\mathrm{b}}$ & - & & - & & 2.1 & (1) & - & 1 & - & - \\
\hline Cortinarius group $5^{\mathrm{a}}$ & - & & 1.4 & (1) & - & & - & - & - & - \\
\hline RFLP02 & - & & 1.4 & (1) & - & & - & - & - & - \\
\hline RFLP13 & - & & 1.4 & (1) & - & & - & - & - & - \\
\hline Hebeloma crustuliniforme & 1.4 & (1) & - & & - & & - & - & - & - \\
\hline Inocybe soluta & 1.4 & (1) & - & & - & & - & - & - & - \\
\hline Cortinarius group $2^{\mathrm{a}}$ & - & & - & & 1.1 & (1) & - & - & - & - \\
\hline Cortinarius group $6^{\mathrm{a}}$ & - & & - & & 1.1 & (1) & - & - & - & - \\
\hline Cortinarius group $7^{\mathrm{a}}$ & - & & - & & 1.1 & (1) & - & - & - & - \\
\hline Lactarius group $^{\mathrm{a}}$ & - & & - & & 1.1 & (1) & - & - & - & - \\
\hline Mycelia sterilia type $14 / 16 / 39^{\mathrm{b}}$ & - & & - & & 1.1 & (1) & - & - & - & - \\
\hline RFLP04 & - & & - & & 1.1 & (1) & - & - & - & - \\
\hline RFLP05 & - & & - & & 1.1 & (1) & - & - & - & - \\
\hline RFLP07 & - & & - & & 1.1 & (1) & - & - & - & - \\
\hline RFLP08 & - & & - & & 1.1 & (1) & - & - & - & - \\
\hline RFLP09 & - & & - & & 1.1 & (1) & - & - & - & - \\
\hline RFLP10 & - & & - & & 1.1 & (1) & - & - & - & - \\
\hline RFLP16 & - & & - & & 1.1 & (1) & - & - & - & - \\
\hline RFLP17 & - & & - & & - & & 1 & - & - & - \\
\hline RFLP18 & - & & - & & - & & - & 1 & - & - \\
\hline RFLP19 & - & & - & & - & & 1 & - & - & - \\
\hline No. of species/RFLP types & 15 & & 20 & & 30 & & 8 & 8 & 3 & 5 \\
\hline No. of successfully analyzed tips & 71 & & 70 & & 95 & & 12 & 14 & 7 & 5 \\
\hline No. of species/RFLP types (rarefaction $n=70$ ) & 15 & & 20 & & 26 & & & & & \\
\hline Shannon's index of diversity & 1.61 & & 2.30 & & 2.74 & & & & & \\
\hline
\end{tabular}

Values give the percentage of mycorrhizal root tips colonized by the respective RFLP type in each site in the soil layer A $(0-5 \mathrm{~cm})$. The values are summed up over all five replicate trees, and the number of trees on which the RFLP type was detected is given in parentheses. Additionally, for each species, the numbers of root tips colonized in deeper soil layers B $(5-20 \mathrm{~cm})$, and C $(20-30 \mathrm{~cm})$ are given for Alzbetinka (Alz) and Modry dul (Mod; no roots were present below $5 \mathrm{~cm}$ in Mumlavska hora).

${ }^{a}$ Several species within the respective genus showed the same RFLP pattern. Clavulina group: C. cristata, C. cinerea, C. rugosa; Cortinarius group 1: C. albovariegatus, C. acutus, C. casimiri, C. decipiens, C. flexipes, C. rigens, C. angelesianus, C. colus, C. damascenus, C. paleiferus, C. parvannulatus, C. subsertipes, C. evernius; Cortinarius group 2: C. uraceus, C. bataillei, C. gentilis, Cortinarius group 4: C. anomalus, C. latobalteatus; Cortinarius group 5: C. cinnamomeus, C. croceus; Cortinarius group 6: C. malicorius, C. violaceomaculatus; Cortinarius group 7: C. sanguineus, C. olivaceofuscus, C. sommerfeltii; Lactarius group: L. subsericatus, L. badiosanguineus, L. sphagneti

${ }^{\mathrm{b}}$ These taxa were isolated from rhizospheric and mycorrhizoplanic fractions of roots of the same trees as sampled in the present study (Nicolotti, unpublished). 
Table 4 Richness and diversity of ectomycorrhizal species on the root system of adult spruce trees, of spruce seedlings from the field, and of seedlings from the soil bioassay

\begin{tabular}{|c|c|c|c|c|}
\hline & Mumlavska hora & Alzbetinka & Modry dul & $p$ value \\
\hline \multicolumn{5}{|l|}{ Adult spruce trees ${ }^{\mathrm{a}}$} \\
\hline \multicolumn{5}{|l|}{ RFLP types } \\
\hline No. of types ${ }^{b}$ & $3.8 \pm 0.3 \mathrm{a}$ & $5.2 \pm 0.6 \mathrm{ab}$ & $6.6 \pm 0.4 b$ & 0.004 \\
\hline Shannon's Index & $1.1 \pm 0.1 \mathrm{a}$ & $1.6 \pm 0.1 \mathrm{~b}$ & $2.0 \pm 0.1 \mathrm{~b}$ & 0.001 \\
\hline \multicolumn{5}{|c|}{ Spruce seedlings (field) ${ }^{\mathrm{c}}$} \\
\hline \multicolumn{5}{|l|}{ Morphotypes } \\
\hline No. of types & $4.7 \pm 1.9$ & $4.5 \pm 0.5$ & $6.5 \pm 0.9$ & nd \\
\hline Shannon's Index & $0.9 \pm 0.5$ & $1.1 \pm 0.1$ & $0.8 \pm 0.1$ & nd \\
\hline \multicolumn{5}{|c|}{ Spruce seedlings (bioassay) ${ }^{\mathrm{d}}$} \\
\hline \multicolumn{5}{|c|}{ RFLP types (living/dead) ${ }^{\mathrm{e}}$} \\
\hline No. of types ${ }^{b}$ & $4.1 / 3.4$ & 4.6 & 5.3 & nd \\
\hline Shannon's Index & $1.4 / 1.2$ & 1.2 & 1.8 & nd \\
\hline
\end{tabular}

nd not determined

${ }^{\text {a }}$ The numbers are means \pm standard errors of five replicate trees per plot. Different letters within lines indicate significant differences of means $(p<$ 0.05 , Bonferroni adjusted).

${ }^{\mathrm{b}}$ Species richness using rarefaction (Hurlbert 1971) for a sample size of 10 mycorrhizas.

${ }^{\mathrm{c}}$ The numbers are means \pm standard errors of six, two, and three replicate seedlings for Mumlavska hora, Alzbetinka, and Modry dul, respectively.

${ }^{\mathrm{d}}$ The numbers are calculated from a total of $30,14,26$, and 22 analyzed root tips for Mumlavska hora living trees, Mumlavska hora dead trees, Alzbetinka, and Modry dul, respectively.

${ }^{\mathrm{e}}$ Soil monoliths for the biotest were excavated close to living or dead trees.

trees being more scattered on the first two ordination axes. These results were more pronounced when the influence of abundant types (e.g., T. fibrillosa) was not reduced by square-root transformation (data not shown). However, since the variation explained by the first two axes, on which the sites were more or less separated, was only $17 \%$ and $15 \%$, the species compositions of the three sites were rather similar.

To obtain information about the ectomycorrhizal species composition in deeper soil layers, we successfully analyzed a total of 38 root tips (19 Alzbetinka, 19 Modry dul). No root tips were found below $5 \mathrm{~cm}$ in the most damaged site, Mumlavska hora. In Alzbetinka and Modry dul, 13 different RFLP types were detected in soil layers below $5 \mathrm{~cm}$ (Table 3). Three unknown RFLP types were not detected in the upper horizon. One of them (RFLP18) probably belongs to the genus Amanita as it has the same RFLP patterns for the enzymes HinfI and MboI as Amanita spissa and Amanita rubescens. Eight RFLP types each were detected in the 5-20 cm layer in Alzbetinka and Modry dul from 12 and 14 analyzed root tips, respectively (Table 3 ). In layers from 20-30 cm, we detected only two RFLP types from seven analyzed root tips in Alzbetinka, whereas in Modry dul, all five analyzed root tips belonged to different types. Among the known RFLP types, Clavulina sp. seemed to be especially abundant below $5 \mathrm{~cm}$ reaching depths up to $30 \mathrm{~cm}$. Six of the seven analyzed root tips in the $20-30 \mathrm{~cm}$ layer were formed by this species in Alzbetinka. Other species found in the deeper soil layers were Russula sp. (R. emetica, Russula ochroleuca, Russula xerampelina), H. pustulatus, Cortinarius caninus, T. asterophora, and T. fibrillosa (Table 3).

Ectomycorrhizal species composition on the roots of seedlings

The roots of seedlings from the field and from the soilbioassay were completely mycorrhizal in all sites. In total, 17 different morphotypes were characterized on the 1-yearold seedlings excavated in Mumlavska hora, Alzbetinka, and Modry dul (data not shown). Although the mean number of morphotypes on seedlings was higher in the less damaged site Modry dul (6.5) than in the other two (4.5 and 4.7; Table 4), the variation was high, ranging from four to ten types in Modry dul and from one to seven types in Mumlavska hora. There were no obvious differences in the ectomycorrhizal composition on the seedlings in the different sites. One of the most abundant morphotype on all sites was bright brown in color with some cystidia, external hyphae, and thin rhizomorphs. It comprised between $7 \%$ and $100 \%$ (one seedling from Mumlavska hora) of the root tips per seedling. DNA analysis revealed that this morphotype was formed by Thelephora terrestris. However, of the several root tips sampled from this morphotype, only two tips have been successfully DNAanalyzed. Both unfortunately originated from Mumlavska hora. Therefore, this morphotype might be formed by different species in the other two sites. T. fibrillosa was also abundant, with mean proportions of $11 \%$ in Modry dul and $36-37 \%$ in the other two sites. DNA analysis showed that 


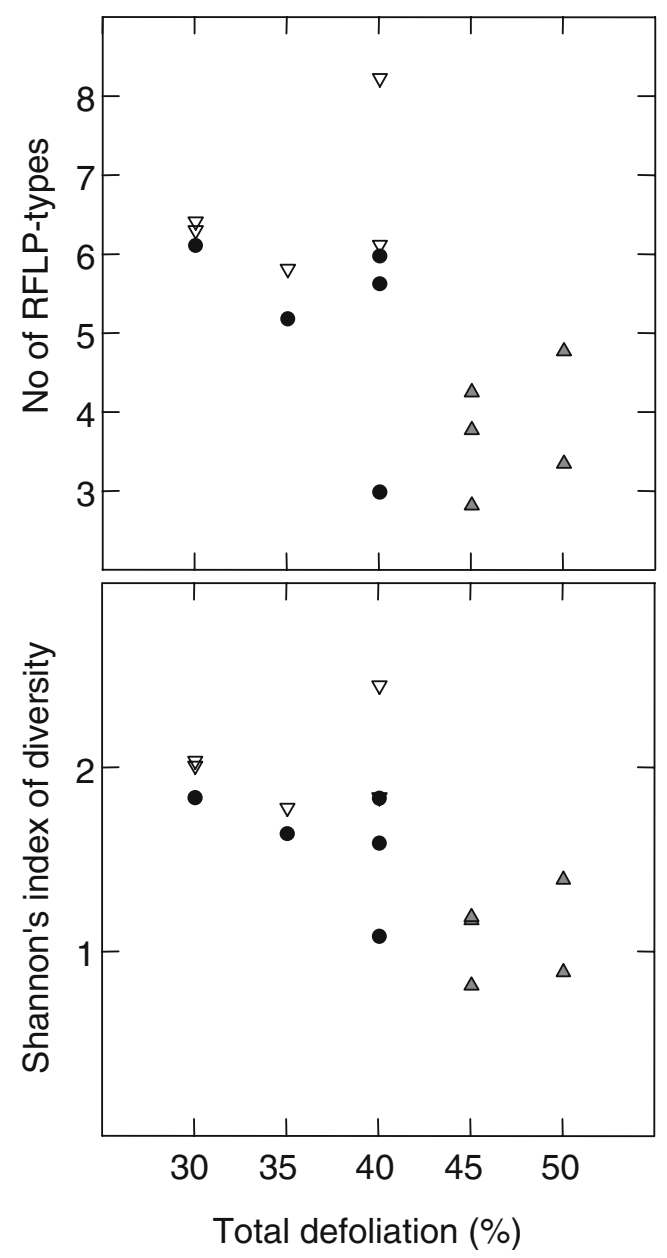

Fig. 2 Relation between richness and diversity of ectomycorrhizas on the root system and the defoliation percentages of the trees. Each point corresponds to one of the five replicate trees studied in sites Mumlavska hora (closed triangles), Alzbetinka (closed circles), and Modry dul (open triangles)

five morphotypes were formed by this species. In general, DNA analysis revealed that, when several root tips of the same morphotype were analyzed, they consistently showed the same RFLP-pattern. Apart from T. fibrillosa, each RFLP type also formed only one morphotype.

From bioassay seedlings, 92 of the 154 root tips sampled were successfully analyzed by molecular tools. DNA analyses indicated that the number of ectomycorrhizal species that are active in colonizing seedlings by spores or resistant propagules was lowest (four) in close proximity to dead trees in the most damaged site Mumlavska hora and highest (nine) in the less damaged site Modry dul (Tables 4 and 5). The sampling regime was not strictly quantitative since root tips were not randomly chosen. The analysis, nevertheless, provided some indication of ectomycorrhizal species abundances. T. fibrillosa was again found abundantly in all sites. T. terrestris was exclusively detected with high abundance on the root system of seedlings grown on soil monoliths excavated close to dead spruce trees in Mumlavska hora.

\section{Discussion}

Ectomycorrhizal species composition in a heavily damaged forest stand and possible causes of the observed differences in the other two study sites

Both the roots of adult trees and seedlings were fully mycorrhizal in the most damaged forest at Mumlavska hora. Ectomycorrhizal inoculum, colonizing roots from spores or resistant propagules, was present in all sites, although it was less species rich in Mumlavska hora. We therefore assume that the observed lack of natural regeneration in the severely damaged forest Mumlavska hora is not primarily caused by an absence of ectomycorrhizal partners.

The fact that the ectomycorrhizal species richness and composition on the root system were different in the most damaged site than in the other two raises several questions: (1) What could be the reason for the observed differences? Are they directly caused by the damage status of the trees or due to different site characteristics? (2) If we consider the damage status of the forest to be the major cause of the reduced species richness, what determines the persistence of ectomycorrhizal species in such forests and the disappearance of others? (3) What is the functional significance

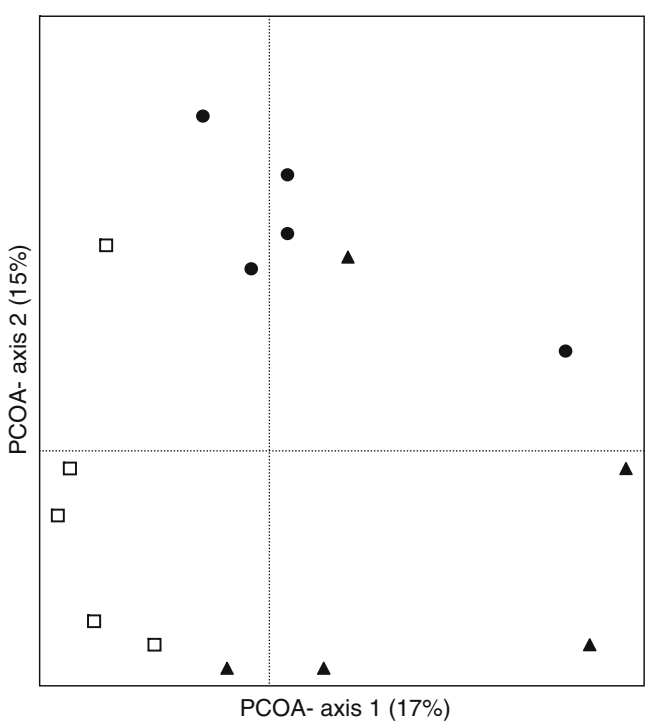

Fig. 3 Variability of the ectomycorrhizal species composition on the root system of 15 spruce trees situated in the three differently damaged forest sites Mumlavska hora (most damaged; open squares), Alzbetinka (circles), and Modry dul (triangles). The plot shows the first two axes of a principal coordinate analysis (PCOA) calculated from RFLP type data. Percentages give the variation explained by the two axes 
Table 5 Ectomycorrhizal species composition on the root system of four-month-old spruce seedlings

\begin{tabular}{|c|c|c|c|c|}
\hline & \multicolumn{2}{|c|}{ Mumlavska hora } & \multirow[t]{2}{*}{ Alzbetinka } & \multirow{2}{*}{$\begin{array}{l}\text { Modry } \\
\text { Dul }\end{array}$} \\
\hline & $\begin{array}{l}\text { Living } \\
\text { trees }\end{array}$ & $\begin{array}{l}\text { Dead } \\
\text { trees }\end{array}$ & & \\
\hline Tylospora fibrillosa & 14 & 5 & 9 & 6 \\
\hline Phialocephala fortinii & 3 & - & 1 & 10 \\
\hline Thelephora terrestris & - & 11 & - & - \\
\hline Tylospora asterophora & 1 & 5 & 1 & 1 \\
\hline $\begin{array}{l}\text { Cenococcum } \\
\text { geophilum }\end{array}$ & 5 & 1 & 1 & - \\
\hline Russula ochroleuca & - & - & - & 6 \\
\hline Clavulina group ${ }^{\mathrm{a}}$ & - & - & 1 & 1 \\
\hline Inocybe soluta & - & - & - & 2 \\
\hline RFLP20 & 2 & - & - & - \\
\hline RFLP18 & - & - & - & 2 \\
\hline Lactarius group $^{\mathrm{a}}$ & - & - & - & 1 \\
\hline Russula emetica & - & - & 1 & - \\
\hline RFLP01 & - & - & - & 1 \\
\hline RFLP21 & 1 & - & - & - \\
\hline $\begin{array}{l}\text { No. of successfully } \\
\text { analyzed tips }\end{array}$ & 26 & 22 & 14 & 30 \\
\hline $\begin{array}{l}\text { No. of species/RFLP } \\
\text { types }\end{array}$ & 6 & 4 & 6 & 9 \\
\hline $\begin{array}{l}\text { No. of species/RFLP } \\
\text { types (rarefaction } n=10 \text { ) }\end{array}$ & 4.1 & 3.4 & 4.6 & 5.3 \\
\hline
\end{tabular}

The seedlings were grown on soil monoliths excavated close to spruce trees from Mumlavska hora, Alzbetinka, and Modry dul. The values are the numbers of root tips on which the respective species/RFLP type was identified.

${ }^{\text {a }}$ Several species within the respective genus showed the same RFLP pattern. Clavulina group: C. cristata, C. cinerea, C. rugosa; Lactarius group: L. subsericatus, L. badiosanguineus, L. sphagneti

of this reduced and altered ectomycorrhizal community on the root system for the host tree?

Looking at the characteristics of the three forest stands, they were similar in terms of altitude, precipitation, and soil chemical properties such as soil $\mathrm{pH}$, heavy metal, and nitrogen content (Zanini et al., unpublished; Bonifacio et al. 2006). The most obvious differences in the soil chemical properties were a smaller cation exchange capacity and soil base saturation in the most damaged site Mumlavska hora (Novak 2001). A few studies have reported on the effect of base saturation on ectomycorrhizal communities. In a study across beech forests in Sweden, Tyler (1985) observed a negative relationship between base saturation and richness, as well as the number of fruitbodies of ectomycorrhizal fungi. The same was found in an $\mathrm{N}$-free fertilization experiment (Wiklund et al. 1995). This does not correspond with our findings. In a recent study, Toljander et al. (2006) showed that the ectomycorrhizal community structure along a local nutrient gradient in a boreal forest was correlated with soil characteristics, in particular extractable ammoni- um and base saturation. However, since these parameters showed a strong and significant positive correlation, it was not possible to show the effect of soil base saturation alone.

We assume that different concentrations of available sulfur had been present in the soil in the three sites. In Mumlavska hora, fulvic acids were richer in sulfur than the ones in Modry dul, which was thought to be primarily caused among others by different $\mathrm{SO}_{2}$ exposure of the sites (Bonifacio et al. 2006). The effect of sulfur deposition on ectomycorrhizal communities has not received much attention (Cairney and Meharg 1999). The studies that do exist are inconclusive but seem to indicate no $\mathrm{SO}_{2}$ effect (review see Cairney and Meharg 1999; Carfrae et al. 2006).

Another important difference between the soil properties of the most damaged site compared to the other two was the fact that it was less well drained and therefore more often saturated (Bonifacio et al. 2006). Bonifacio et al. (2006) suggest that the pedogenic process was intensified towards podzolization, probably because of the different geomorphology of Mumlavska hora. This site is located on a mountain top, whereas Alzbetinka and Modry dul are situated on steep slopes. A less steep slope allows for a major amount of water to be available for translocation throughout the profile and water saturation when the iron pan is present. It is possible that both water logging and the combination of water logging and soil chemical properties (e.g., low $\mathrm{pH}$ and base saturation) may affect ectomycorrhizal species composition. Stenstrom (1991) reported that ectomycorrhizal species varied in their sensitivities to flooding in colonizing roots. T. terrestris, for example, was found abundantly on the roots of seedlings in the most damaged site and seems to tolerate flooding, whereas Suillus species failed to colonize the roots when flooded even for only short periods of time (Stenstrom 1991). High abundances of up to $70 \%$ on the root system of adult trees were also reported for T. fibrillosa from monocultures of Sitka spruce growing in frequently water-logged, anoxic soils in Northern England (Palfner et al. 2005). Beside the dominant $T$. fibrillosa, three of the five species that fruited in the Mumlavska hora forest $(C$. croceus, H. olivaceoalbus, $R$. emetica) were also present in this plantation. They are either known to be common on damp and boggy sites (R. emetica, C. croceus) (Palfner et al. 2005), as $L$. sphagneti (Moser 1983), which also fruited in the Mumlavska hora forest, or they produce abundant fruitbodies in conifer forests irrespective of the $\mathrm{N}$-status of the soil $(H$. olivaceoalbus, H. pustulatus) (Lilleskov et al. 2001; Peter et al. 2001a, b).

Differences in soil conditions are likely to be present because of the different forest densities. These affect the floor vegetation, e.g., there are more grasses in open forests (Bonifacio et al. 2006), and possibly also affect the fitness and thus the composition of different mycorrhizal fungi. 
The most striking difference between the Mumlavska hora site and the other two was the reduced number of living trees and the higher proportion of defoliation and secondary shoots of these trees. According to (Cudlín et al. 2001), secondary shoots are continuously formed to replace damaged assimilative organs, which results in additional carbon consumption. Both defoliation and secondary shoot formation probably influence the quantity of carbon allocated to the roots and associated ectomycorrhizal fungi. Fruitbody surveys show that in air-polluted forest sites (mostly $\mathrm{N}$-compounds and $\mathrm{SO}_{2}$ ), with or without signs of forest decline, almost exclusively ectomycorrhizal species decline in abundance, whereas other functional groups of soil fungi are less affected (Arnolds 1991; Fellner and Pešková 1995). This suggests that the observed differences might not be the result of a direct impact on ectomycorrhizal fungi of the different soil properties in these polluted sites since unfavorable soil conditions would be likely to affect different functional groups of soil fungi similarly.

Mycorrhizal species are directly dependent on the carbon supply from living plants. The reduced mycorrhizal fruitbody production and/or mycorrhiza formation in the more severely damaged site may be at least partly explained by the reduced allocation of carbon from the plant to the fungus and a reduced fungal investment of the carbon in reproduction. The observed reduced fruitbody abundance of ectomycorrhizal species in airpolluted sites in Europe (Arnolds 1991) is thought to be due in particular to increased nitrogen deposition, which has been shown to reduce ectomycorrhizal fruitbody abundance as well as species richness and composition (Lilleskov et al. 2001; Peter et al. 2001a, b; Lilleskov et al. 2002; Avis et al. 2003). One of the important causes of this is assumed to be the reduction in the carbon supply from the plant to the fungus, since the provision of carbon skeletons for $\mathrm{N}$ assimilation within the plant is enhanced at higher $\mathrm{N}$ levels in roots and leaves (Champigny 1995; Wallenda and Kottke 1998).

It has repeatedly been demonstrated that an interruption or a reduction of the carbon supply from the host tree affects ectomycorrhizal fruitbody production and/or mycorrhizal colonization. Ectomycorrhizal fruitbody production ceased after clear cutting (Kropp and Albee 1996; Visser and Parkinson 1999) or tree girdling (Hogberg et al. 2001). Herbivory or artificial defoliation generally reduced ectomycorrhizal colonization or altered their community composition (Cullings et al. 2001; Gehring and Whitham 2002; Kuikka et al. 2003; Mueller et al. 2005). The latter was possibly the result of an increased carbon allocation to mycorrhizal species with low carbon requirements or with carbon-degrading abilities (Markkola et al. 2004; Cullings et al. 2005). Because fungal biomass in the roots and the colonization percentage remained unchanged, Kuikka et al.
(2003) concluded from their defoliation experiment that even severely defoliated trees continued to invest in the maintenance of the symbiosis despite the reduced photosynthetic capacity. The results of our study support these findings by showing that even roots of trees in the most damaged site were fully mycorrhizal.

In this respect, we speculate that species being able to persist or even increase in abundance on the root system in the heavily damaged forest Mumlavska hora might be more efficient in taking up carbon for vegetative spread and colonization of roots or they might have access to other carbon sources than those directly mediated by the living plant. Ectomycorrhizal fungi are known to have saprotrophic capabilities (Read and Perez-Moreno 2003; Courty et al. 2005). In the present study, the most abundant species in the Mumlavska hora forest was T. fibrillosa, which is known to have decomposing and proteolytic abilities (Ryan and Alexander 1992; Cairney and Burke 1994). It made up more than $60 \%$ of all the analyzed root tips in this site and its proportion was twice that in the other two sites. $T$. fibrillosa forms inconspicuous, resupinate fruitbodies, which might be an additional advantage since they are possibly less carbon costly than large ones. Once formed, they enhance spread by spores. It is interesting to note that the bioassay revealed that only species from the thelephoroids and athelioids (T. terrestris, T. fibrillosa, T. asterophora) and Cenococcum geophilum were able to colonize seedlings in soils excavated close to dead trees in Mumlavska hora. These species might be present as resistant propagules (e.g., C. geophilum) or their spores are abundant. It is possible also that their mycelia are able to survive and colonize seedlings even when disconnected to trees if they do have saprotrophic capabilities. For $T$. terrestris, which is known to be a common colonizer of noninoculated seedlings grown in greenhouses, the high abundance of this species on seedlings grown on soil monoliths excavated close to dead trees might be a greenhouse artefact. The fact that it was exclusively detected in soil monoliths excavated close to dead trees could indicate that in these soils the inoculum potential was lower than in the other monoliths and only therefore the greenhouse contaminant was able to colonize roots. However, this species was also abundant on seedlings grown naturally in the field in Mumlavska hora, which supports our findings in the bioassay as being no artefact. Members of the thelephoroids and athelioids are important components of the ectomycorrhizal community on the root system in most temperate and boreal forest ecosystems (Erland and Taylor 1999; Dahlberg 2001; Horton and Bruns 2001). Increasing abundances of such species have previously been reported from stressed environments or from less vital trees: in sites with high $\mathrm{N}$-deposition or artificial $\mathrm{N}$-fertilization, $T$. fibrillos $a$ and other members of these taxa 
seem to be more abundant at the root level than in less Npolluted control sites (Kårén and Nylund 1997; Peter et al. 2001a, b; Lilleskov et al. 2002). Nara et al. (2003) showed that species forming inconspicuous fruitbodies, such as those belonging to the Thelephoraceae, Sebacina sp., and C. geophilum, were significantly more abundant on less vital Salix trees with less growth, lower nutrient concentrations, and less photosynthetic activity than on healthy ones in a primary succession site in a volcanic desert. In a windthrow plot with no persisting adult trees, Egli et al. (2002) observed 10 years after the storm that seedlings had been almost exclusively colonized by $T$. terrestris and $T$. asterophora. The role these fungi play may therefore be even more important under such stressed conditions.

It is unclear whether a reduced and different composition of ectomycorrhizal fungi provides all the benefits of the ectomycorrhizal symbiosis for the host trees. Answering questions about the functional significance of a shift in ectomycorrhizal symbionts will be difficult until we know more about the intra- and interspecific physiological properties of these fungi. We have, however, evidence from inoculation experiments that plants associated with only one ectomycorrhizal species still grow better than noninoculated plants, particularly in harsh environments (Smith and Read 1997). It seems then that the persisting fungi, such as T. fibrillosa and T. terrestris in the present study, should be sufficient to support natural regeneration.

\section{Comparison of ectomycorrhizal community compositions} in the present and other conifer stands

The ectomycorrhizal species richness and compositions found at the root level in the two sites, Modry dul and Alzbetinka, are generally similar to other belowground surveys in conifer stands (Taylor et al. 2000; Horton and Bruns 2001; Peter et al. 2001a, b). Dahlberg et al. (1997), for example, identified 25 species of 70 DNA-analyzed root tips in a 100-year-old Norway spruce stand in Sweden, whereas we detected 25 species in our least damaged forest, 20 in the moderately damaged one, and 15 in the most damaged forest. In a study of three Norway spruce stands in Switzerland (Peter et al. 2001a, b), estimated species richness using rarefaction of 45 root tips to be between 23 in over 100-year-old forests and 15 in a 35 -year-old forest. This compares with 19,15 , and 12 species in the present study. The general pattern of finding a few abundant and many rare species (cf. Dahlberg 2001) applies also to the present plots. However, a dominance of only one species with more than $60 \%$, as found in the Mumlavska hora plot, has seldom been reported and might indicate stressed environments. For example, up to $80 \%$ of roots were colonized by $C$. geophilum along a chronosequence of red oak stands on a forest reclamation site with disturbed soil in a lignite mining area (Gebhardt et al. 2007). In a white spruce stand with high $\mathrm{N}$ deposition close to a fertilizer facility, Lactarius theiogalus dominated with a proportion of $69 \%$ (Lilleskov et al. 2002). T. fibrillosa dominated with $70 \%$ in a Sitka spruce plantation on a frequently waterlogged, anoxic soil in Northern England (Palfner et al. 2005).

Acknowledgements The authors would like to thank Simone Falcato for assistance in morphotype and DNA analyses and Silvia Dingwall for language help. This study was funded by the European project "Sustainable bio-technologies against forest regeneration decline and soil erosion in North-Eastern Bohemia" (SUSBIOFOR), a project of MZP CR OC E38.001 and research plan of CAS AV0Z60870520.

\section{References}

Agerer R (1991) Characterization of ectomycorrhiza. Method Microbiol 23:26-73

Arnolds E (1991) Decline of ectomycorrhizal fungi in Europe. Agric Ecosyst Environ 35:209-244

Avis PG, McLaughlin DJ, Dentinger BC, Reich PB (2003) Long-term increase in nitrogen supply alters above-ground and belowground ectomycorrhizal communities and increases the dominance of Russula spp. in a temperate oak savanna. New Phytol 160:239-253

Bonifacio E, Santoni S, Celi L, Zanini E (2006) Spodosol-Histosol evolution in the Krkonose National Park (CZ). Geoderma 131:237-250

Cairney J, Burke R (1994) Fungal enzymes degrading plant cell walls: their possible significance in the ectomycorrhizal symbiosis Mycol Res 98:1345-1356

Cairney J, Meharg A (1999) Influences of anthropogenic pollution on mycorrhizal fungal communities. Environ Pollut 106:169-182

Carfrae JA, Skene KR, Sheppard LJ, Ingleby K, Crossley A (2006) Effects of nitrogen with and without acidified sulphur on an ectomycorrhizal community in a Sitka spruce (Picea sitchensis Bong. Carr) forest. Environ Pollut 141:131-138

Champigny M (1995) Integration of photosynthetic carbon and nitrogen metabolism in higher plants. Photosynth Res 46:117127

Courty P-E, Pritsch K, Schloter M, Hartmann A, Garbaye J (2005) Activity profiling of ectomycorrhiza communities in two forest soils using multiple enzymatic tests. New Phytol 167:309-319

Cudlín P, Novotný R, Moravec I, Chmelíková E (2001) Retrospective evaluation of the response of Montaine forest ecosystems to multiple stress. Ekológia (Bratislava) 20:108-124

Cudlín P, Godbold DL, Bonifacio E, Egli S, Fritz H, Gonthier P, Chmelíková E, Kowalik P, Martinotti M, Moravec I, Nicolotti G, Varese C, Peter M, Zanini E (2003) Conditions of natural regeneration of Norway spruce ecosystems in the Krkonose Mountains. Ekológia (Bratislava) 22(Supplement 1/2003):66-79

Cullings KW, Vogler DR, Parker VT, Makhija S (2001) Defoliation effects on the ectomycorrhizal community of a mixed Pinus contorta/Picea engelmannii stand in Yellowstone Park. Oecologia 127:533-539

Cullings K, Raleigh C, Vogler DR (2005) Effects of severe dwarf mistletoe infection on the ectomycorrhizal community of a Pinus contorta stand in Yellowstone Park. Can J Bot 83:1174-1180

Dahlberg A (2001) Community ecology of ectomycorrhizal fungi: an advancing interdisciplinary field. New Phytol 150:555-562 
Dahlberg A, Jonsson L, Nylund JE (1997) Species diversity and distribution of biomass above and below ground among ectomycorrhizal fungi in an old-growth Norway spruce forest in south Sweden. Can J Bot 75:1323-1335

Egli S, Peter M, Falcato S (2002) Dynamics of ectomycorrhizal fungi after windthrow. For Snow Landsc Res 77:81-88

Erland S, Taylor AFS (1999) Resupinate ectomycorrhizal genera. In: Cairney JWG, Chambers SM (eds) Ectomycorrhizal fungi. Key genera in profile. Springer, Heidelberg, pp 347-363

Fellner R, Pešková V (1995) Effects of industrial pollutants on ectomycorrhizal relationships in temperate forests. Can J Bot 73 (Suppl. 1):S1310-S1315

Gebhardt S, Neubert K, Wöllecke J, Münzenberger B, Hüttl R (2007) Ectomycorrhiza communities of red oak (Quercus rubra L.) of different age in the Lusatian lignite mining district, East Germany. Mycorrhiza 17:279-290

Gehring C, Whitham TG (2002) Mycorrhiza-herbivore interactions: population and community consequences. In: van der Heijden MGA, Sanders IR (eds) Mycorrhizal ecology. Springer, New York, pp 295-320

Gillman GP (1979) A proposed method for the measurement of exchange properties of highly weathered soils. Aust J Soil Res 17:129-139

Gruber F (1994) Morphology of coniferous trees: possible effects of soil acidification on the morphology of Norway spruce and silver fir. In: Godbold DL, Hütterman A (eds) Effects of acid rain on forest processes. Wiley, New York, pp 265-324

Hadaš P (1994) Krkonose. Climatic and immission situation on the territory of the Krkonose National Park. In: Final Report of the Project VaV MZP Monitoring and Modelling of Forest Response to Air Pollution and Soil Acidification, IFER, Jilove u Prahy, CZ, p 13

Henzlik V, Gutkowski RM, Winnicki T (1997) Forests and air pollution in the Czech Republic. In: Gutkowski RM, Winnicki $\mathrm{T}$ (eds) Restoration of forests-environmental challenges in central and eastern Europe. Kluwer, Dordrecht, pp 133-149

Hogberg P, Nordgren A, Buchmann N, Taylor AFS, Ekblad A, Hogberg MN, Nyberg G, Ottosson-Lofvenius M, Read DJ (2001) Large-scale forest girdling shows that current photosynthesis drives soil respiration. Nature 411:789-792

Horton T, Bruns TD (2001) The molecular revolution in the ectomycorrhizal ecology: peeking into the black-box. Mol Ecol 10:1855-1871

Hruška J, Cudlín P (2003) Ratio of base cations and aluminium and spruce stand status in the Czech Republic. In: Hruška J, Cienciala $\mathrm{E}$ (eds) Long-term acidification and nutrient degradation of forest soils-limiting factors of forestry today. Czech Ministry of Environment, Prague, CZ

Hurlbert SH (1971) The nonconcept of species diversity: a critique and alternative parameters. Ecology 52:577-586

Innes JL (1993) Forest health: Its assessment and status, CAB International, pp 672

Jansen AE (1991) The mycorrhizal status of Douglas Fir in the Netherlands: its relation with stand age, regional factors, atmospheric pollutants and tree vitality. Agric Ecosyst Environ 35:191-208

Jeník J (1961) Alpine vegetation of the Krkonose, Kralicky Sneznik and Hruby Jeseník Mts. CSAV, Praha, CZ, p 409

Kårén O, Nylund JE (1997) Effects of ammonium sulphate on the community structure and biomass of ectomycorrhizal fungi in a Norway spruce stand in southwestern Sweden. Can J Bot $75: 1628-1642$

Kårén O, Högberg N, Dahlberg A, Jonsson L, Nylund JE (1997) Interand intraspecific variation in the ITS region of rDNA of ectomycorrhizal fungi in Fennoscandia as detected by endonuclease analysis. New Phytol 136:313-325
Kielszewska-Rokicka B, Rudawska M, Leski T (1997) Ectomycorrhizae of young and mature scots pine trees in industrial regions in Poland. Environ Pollut 98:315-324

Kropp BR, Albee S (1996) The effects of silvicultural treatments on occurrence of mycorrhizal sporocarps in a Pinus contorta forest: a preliminary study. Biol Conserv 78:313-318

Kuikka K, Harma E, Markkola A, Rautio P, Roitto M, Saikkonen K, Ahonen-Jonnarth U, Finlay R, Tuomi J (2003) Severe defoliation of Scots pine reduces reproductive investment by ectomycorrhizal symbionts. Ecology 84:2051-2061

Lilleskov EA, Fahey TJ, Lovett GM (2001) Ectomycorrhizal fungal aboveground community change over an atmospheric nitrogen deposition gradient. Ecol Appl 11:397-410

Lilleskov EA, Fahey TJ, Horton TR, Lovett GM (2002) Belowground ectomycorrhizal fungal community change over a nitrogen deposition gradient in Alaska. Ecology 83:104-115

Manion PD (1991) Tree desease concepts. Prentice Hall, Engelwood Cliffs, NJ, USA, p 402

Markkola A, Kuikka K, Rautio P, Härmä E, Roitto M, Tuomi J (2004) Defoliation increases carbon limitation in ectomycorrhizal symbiosis of Betula pubescens. Oecologia 140:234-240

Moser M (1983) Die Röhrlinge und Blätterpilze (Polyporales, Boletales, Agaricales, Russulales), Gustav Fischer Verlag, Stuttgart, DE, pp 1-533

Mueller RC, Sthultz CM, Martinez T, Gehring CA, Whitham TG (2005) The relationship between stem-galling wasps and mycorrhizal colonization of Quercus turbinella. Can J Bot 83:13491353

Nara K, Nakaya H, Wu B, Zhou Z, Hogetsu T (2003) Underground primary succession of ectomycorrhizal fungi in a volcanic desert on Mount Fuji. New Phytol 159:193-206

Novak F (2001) Nitrogen transformation in soils of mountain spruce stands. Report Biology Centre, AS CR, České Budějovice, pp 183

Palfner G, Casanova-Katny MA, Read DJ (2005) The mycorrhizal community in a forest chronosequence of Sitka spruce [Picea sitchensis (Bong.) Carr.] in Northern England. Mycorrhiza 15:571-579

Percy KE (2002) Is air pollution an important factor in forest health? In: Szaro RC, Bytnerowicz A, Oszlányi J (eds) Effects of air pollution on forest health and biodiversity in forests of the Carpathian Mountains. IOS Press, Amsterdam, pp 23-42

Peter M, Ayer F, Egli S (2001a) Nitrogen addition in a Norway spruce stand altered macromycete sporocarp production and belowground ectomycorrhizal species composition. New Phytol 149:311-325

Peter M, Ayer F, Egli S, Honegger R (2001b) Above- and belowground community structure of ectomycorrhizal fungi in three Norway spruce stands in Switzerland. Can J Bot 79:1134-1151

Polák T, Cudlín P, Moravec I (2007) Macroscopic indicators for the retrospective assessment of Norway spruce crown response to stress in the Krkonoše Mountains. Trees 21:23-35

Read DJ, Perez-Moreno J (2003) Mycorrhizas and nutrient cycling in ecosystems - a journey towards relevance? New Phytol 157:475492

Ryan E, Alexander I (1992) Mycorrhizal aspects of improved growth of spruce when grown in mixed stands of heathland. In: Read D, Lewis D, Fitter A, Alexander I (eds) Mycorrhizas in ecosystems. CAB International, Wallingford, pp 237-245

Schulze E-D, Lange OL, Oren R (1989) Forest Decline and Air Pullution. Springer, Berlin Heidelberg

Schwarz O (2001) Status of forestry in the Krkonose National Park. In: Report of the Project CEC EU SUSBIOFOR. Office of the Krkonose National Park, Vrchlabí, p 69

Smith SE, Read DJ (1997) Mycorrhizal symbiosis. Academic, London, pp 1-605 
Stenstrom E (1991) The effects of flooding on the formation of ectomycorrhizae in Pinus-sylvestris seedlings. Plant Soil $131: 247-250$

SYSTAT (2000) SYSTAT for Windows: Statistics, Version 10. SPSS, Evanston, IL, USA

Taylor AFS, Martin F, Read DJ (2000) Fungal diversity in ectomycorrhizal communities of Norway spruce (Picea abies (L.) Karst.) and Beech (Fagus sylvatica L.) along north-south transects in Europe. In: Schulze E-D (ed) Carbon and nitrogen cycling in European forest ecosystems. Ecological studies, vol. 142. Springer, Heidelberg, Germany, pp 343-365

Toljander JF, Eberhardt U, Toljander YK, Paul LR, Taylor AFS (2006) Species composition of an ectomycorrhizal fungal community along a local nutrient gradient in a boreal forest. New Phytol 170:873-884

Tyler G (1985) Macrofungal flora of Swedish beech forest related to soil organic matter and acidity characteristics. For Ecol Manag $10: 13-29$
Vacek S, Matějka K (1999) The state of forest stands on permanent research plots in the Krkonoše Mts. in the years 1967-1997. J For Sci 45:291-315

Visser S, Parkinson D (1999) Wildfire vs. clearcutting: impacts on ectomycorrhizal and decomposer fungi. In: Meurisse RT, Ypsilantis WG, Seybold C (eds) Proceedings: Pacific Northwest forest and rangeland soil organism symposium. U.S. Department of Agriculture, Forest Service, Pacific Northwest Research Station, Portland, Oregon, Corvallis USA, pp 114-123

Wallenda T, Kottke I (1998) Nitrogen deposition and ectomycorrhizas. New Phytol 139:169-187

Wiklund K, Nilsson LO, Jacobsson S (1995) Effects of irrigation, fertilization and artificial drought on basidioma production in a Norway spruce stand. Can J Bot 73:200-208

Wildi O, Orlóci L (1996) Numerical exploration of community pattern. A guide to the use of MULVA 5. SPC Academic Publishing, Amsterdam, NL 